International Journal of Current Aspects in Finance, Banking and Accounting, Volume 2, Issue 3, 2020 PP 24-37, ISSN 2707-8035

@JCAB

\title{
Microfinance Services and Performance of Women Owned Business Enterprises in Busia County, Kenya
}

\author{
Christopher Busolo Lusweti ${ }^{1}$ \\ ${ }^{1}$ School of Business, Kenyatta University, Kenya \\ Dr. Evans Mwasiaji² \\ ${ }^{2}$ Department of Entrepreneurship, School of Business of Kenyatta University
}

\section{ABSTRACT}

The main purpose of this study was to determine the effects of microfinance services on women owned enterprises in Busia County. The study specific objectives included, to establish the effects of credit on performance of women owned business enterprises in Busia County, determine the effects of financial training on the performance of women owned enterprises in Busia County, examination of the effects of savings on performance of women owned business enterprises ,conceptualization of the effects of social capital on the performance of women owned business enterprises and examine the effects of legal framework on the inclusive business enterprises performance of women owned enterprises in Busia County. The study was guided mainly by the resource - based view theory and institutional theory, among others. The study adopted a descriptive survey research designs while study target population was 500 women owned entrepreneurs in Busia County, Kenya. Stratified random sampling technique was used and the sample size constituted $20 \%$ of the total target population thus making a simple size of 100 respondents for this study. The respondents were purposively selected women entrepreneurs, customers of the specific selected microfinance institutions found within Busia county business ecosystem. The questionnaires were used as a tool for primary data collection respectively, both qualitative and quantitative data analysis methodologies were applied by use of spss version 23.0.The study findings revealed that, an increase in credit, finance training, social capital, savings and legal framework by one unit leads to an increase in performance by 0.502, 0.124, 0.081, 0.236, and 0.059 units respectively with a $p$-value of $<0.05$ for each variable. Based on the study findings the researcher can conclude that, women owned enterprises are key drivers to the economic development in Kenya and the study recommends that training program should be emphasized to enhance the financial literacy management for exemplary performance of the enterprises. Savings, social capital, financial training, legal framework and credit services significantly influences performances of women-owned business enterprises. According to the research findings, the frequency of trainings should be increased to keep them abreast with modern methodologies for better performance and financial training programs for women owned business enterprises should be designed to meet the standards needs for women entrepreneurs' and more so the aspiring new entrants.

Key Words: Microfinance Services, Credit Finance, Financial Training, Social Capital, Legal Framework, Women Owned Business Enterprises

DOI: DOI 10.35942/ijcfa.v2i2.13

\section{Cite this Article:}

Lusweti, C., \& Mwasiaji, E. (2020). Microfinance Services and Performance of Women Owned Business Enterprises in Busia County, Kenya. International Journal of Current Aspects in Finance, Banking and Accounting, 2(3), 24-37. https://doi.org/10.35942/ijcfa.v2i3.151 
International Journal of Current Aspects in Finance, Banking and Accounting, Volume 2, Issue 3, 2020 PP 24-37, ISSN 2707-8035

[iJCAB

\section{Introduction}

Globally, the microfinance services have been drastically spreading, for example in America the Inter-American Bank states that women have greatly increased their role in work and job market. Three quarters of women in America are economically stable and this number continues to double women since 1970s.In the undeveloped countries, majority of women who owns enterprises in these nations faces challenges of accessing credit of which microfinance institutions objective of providing credit facilities becomes essential(Inter -American Development Bank ,2015). According to international Financial Corporation 2018 reports, microfinance is an important banking service that aren't restricted on the status of employment whether employed or unemployed; these facilities are accessed by all unemployed persons or low income individuals.

This grant groups with other access to financial services have chances at least to obtain such services. In this regard the objective of microfinance is to give low income persons an opportunity to become self-employed. In this regard the objective of microfinance is to give low income persons an opportunity to become economically self-reliant and sufficient by showing them away to save money, access credit facility and even get insurance services. Chile, as a highly developing country; around 33\% of all business people are ladies and this has been expanding 20\% three years back. The gauge is that by 2020 female business entrepreneurs in Chile will rise to be equal to their male counterparts and make over half of the occupation in the new undertakings. According to the international trade Centre 2014 report, Canada has encountered a 200\% development in the quantity of ladies business visionaries in the course of the recent 20 years.

In the late 19180s microfinance organizations came up in the US. They greatly served low finance generating persons and minority in the societies. Microfinance history in Canada came up through creation of credit unions. The credit unions gave financial assistance to Canadians who had never accessed any financial means $t$ support themselves. In the perspective of African continent, for instance, women entrepreneurs in Cameroon manage $57 \%$ of business enterprises; while in Uganda women entrepreneurs form the most the country business people. The other vital aspect is being informed of the ability of the applicant in managing the intended business hence repayment ability in the long run (Blackburn,2014). Women enterprises play vital role and exercise in the monetary extension the entire world and among human inclusive race. Despite of this fundamental job ,researchers have found that women business, have low business muscles in contrast with men and this has been attributed to absence of credit ,reserve funds, financial training ,opaque legal framework and social capital. Subsequently, this has caused poor money realted history for women (Sena,Scott \&Roper,2012).

In creating, countries microfinance establishments benefits a wide scope of administrations, for instance ,stores ,credits, installment administrations, cash movement and protection to low-salary families and their endeavors. According to IFC,(2015)numerous examinations shows that women business is perceived to have higher financing costs and insurance to get a credit, they also need higher portion of advance and approach not just shorter-term advances. Microfinance institutions empower venture proprietors to build up their smaller scale and little business endeavors, which upgrade their salary acquiring limit and consequently appreciate and improved expectation for everyday comforts. Though numerous MFIs developed to lend starting capital and working capital in Kenya, importance and cost-adequacy is frequently wrong in fulfilling the specific needs of potential and working women business visionaries (GoK, 2014). 
International Journal of Current Aspects in Finance, Banking and Accounting, Volume 2, Issue 3, 2020 PP 24-37, ISSN 2707-8035

\section{[IJCAB}

The presence of microfinance establishments empowers the potential customers to get to the administration given by the foundations. These administrations give the clients a chance to help their business endeavors, monetary exercises just as their family unit budgetary needs. Microfinance institutions provides credit services, savings for its subscribers together with necessary financial services within the access of billions of people who are unable to be served by the regular banking institutions due to their inability to offer sufficient collateral items. Microfinance organizations subscribe members whether poor or not unlike banks that go for people with money. Women entrepreneurs are job creators who therefore improve standards of living in the society. In doing this, it provides self-satisfaction, flexibility and independence in the community (Waita, 2012).

Regarding microfinance service access, one major drawback in the African set up is the academic level of the applicant for credit which is important to avoid cases of being misled by lenders. According to Mwobobia (2012) lower education levels of women entrepreneurs denies women appropriate means of accessing entrepreneurship training. It also limits the level of understanding during training. Though majority of Women have the experience and knowledge needed to do well in business the challenges is always seen on accessing capital since culture and tradition on the other hand has hampered them than their counterpart. This skills in business plays a key role to the country's overall economic prosperity. In most Africa countries such as Uganda and Kenya education were limited to the boy child hence making women less informed and this has affected business management by women. This has created a limitation to women on developing their businesses (Women Entrepreneurs in Kenya, 2016).

Kenya's budgetary area developed consistently during the 1990s as shown by the development of the portion of the monetary segment in GDP as the advantages of microfinance organizations expanded by $16 \%$ (Central Bank of Kenya, 2014). As the monetary part develops, institutional decent variety is normal. The Kenyan financial division is commanded by a couple of huge firms, which center predominantly on the present moment. According to majority of researchers' data; women Enterprise Execution is the final product or yield of a given undertaking estimated against present known guidelines of exactness, culmination, cost and speed (Kiraguri, 2012). Therefore, our study is tasked with the responsibility of analyzing the effect of microfinance on the performance of women owned business enterprises in Busia County. The performance of these enterprises will be measured in regard to market share, stock level, and sales volume. Despite the interest rate capping where the interest rate should be not more than $4 \%$ from the central bank rate, microfinance institutions have not reduced their rates which is still a gap in the amendments of interest rates. The high rates have therefore made women owned enterprises not to perform well. However, women still go for credit in these institutions due to easier terms of credit access and non-financial services provided. It is noted with great concern that high expenses, rigidity of collateral demands and tedious paperwork are further hindrances to women entrepreneurs (Karani, 2012).

Women empowerment in African has taken a new twist where the percentage of wealth generation and job creation has increased. It should be noted that in Kenya women are going an extra mile of starting up and running their own businesses apart from competing with men economically and in leadership forums in the corporate arena. In most cases there has been found a considerable differences in men and women access to opportunities to exert power over economic structures. In various contexts, such financial decisions, monetary decisions, commercial decisions and generally the economic policies, women are neglected in decisions that negatively affect 
International Journal of Current Aspects in Finance, Banking and Accounting, Volume 2, Issue 3, 2020 PP 24-37, ISSN 2707-8035

iJCAB

performance of women owned business enterprises. Women in Kenyan rural communities are poor and still face extreme financial hiccups (Kiraguri, 2012). The structural adjustment initiatives by the government have had negative influence on the poor and the less fortunate which are majorly women and children. Steps have been taken by the Kenyan government to promote women economic empowerment, among them is subscribing to microfinance institutions for improvement of women businesses, for instance Kenya Women Finance Trust (KWFT) has championed assistance to women to grow economically. Women in self-employment have greatly increased in recent years and yet the number of women involved in business is lower than that of men, this shows that many women entrepreneurs are operating in more difficult conditions than men entrepreneurs (Karani, 2012). Statistically, women comprise more than half of the Kenyan population and make a notable contribution to the growth of an economy.

\section{Statement of the Problem}

Women entrepreneurship and empowerment plays a great role in the economic development of societies. The aspect of women empowerment clearly enhances economic stability within the family. However, Access to money for startup of a business, operation of businesses and expansion of businesses is one of the major challenges of any entrepreneur with women entrepreneurs facing extra constraints to secure financial muscles (Wole, 2012). For a long time, women entrepreneurs have reported low business performance in relation to businesses owned by men (Kiraguri, 2012) this has continued to have been attributed to factors which normally affect entrepreneurial performance such as lack of credit, savings, education or training, and social capital. Majority of researchers insists that in the under-developed and developing countries such as Kenya, women entrepreneurs are underfunded which creates a problem in running of their businesses Yusuf (2014). While on the other hand, Ochola (2013) states that it is upon this underfunding that special funds concept that includes microfinance and women fund emerged to bridge this gap. Findings continue to indicate that in the developing economy at large; women's access to funding is limited because lending agencies usually require tangible and substantive collateral from borrowers. In funding entities, the most commonly accepted tangible form of collateral is land which most women lack. Furthermore, women entrepreneurs are most times hijacked from managing competitive businesses by their perceived low education and skill levels and this has limited their access to the various support and credit services.(Karwenji (2012). However even though it is acknowledged that women face many barriers in accessing microfinance, studies have failed to address the problem. This is the gap this study sought to address. It focused on effect of the micro finance services' and the performance of women owned business enterprises in Busia County, Kenya. This study therefore identified and sought to answer questions on lack of access to credit, low business performance, inadequate business training, inadequate social capital and legal constrains among others in relation to women owned business enterprises.

\section{Research Objectives}

The general objective of the study was to determine the effect of microfinance on the performance of women owned business enterprises in Busia County -Kenya.

Specifically, the study sought to:

i. To establish the effect of credit on the performance of women owned business enterprises in Busia County, Kenya.

ii. To determine the effect of financial training on the performance of women owned business enterprises in Busia County, Kenya. 
International Journal of Current Aspects in Finance, Banking and Accounting, Volume 2, Issue 3, 2020 PP 24-37, ISSN 2707-8035

[IJCAB
iii. To examine the effect of savings on the performance of women owned business enterprises in Busia County, Kenya.
iv. To conceptualize the effect of social capital on the performance of women owned business enterprises in Busia County, Kenya.
v. To examine the effect of legal framework on the performance of women owned business enterprises in Busia County, Kenya.

\section{Theoretical Review}

This study laid its theoretical concept on resource-based theory and institution theory. Resource based theory points out performance of women owned enterprises in relation to credit and financial training as microfinance services. Institution theory points out performance of women owned enterprises in relation to social capital, savings and legal frame work as microfinance services.

\subsection{Resource Based Theory}

The humanist Philip tale indicates the main issue of asset-based hypothesis; its is a variety of assets and capacities' that fills suffering achievements, no one asset alone. In an undeniable later model, humanist Selznick built up the idea of particular ability. Southwest Airlines gives an outline of asset-based hypothesis in real life situations. Asset based hypothesis battles that the ownership of vital assets gives an association a brilliant chance to create upper hands over its adversaries .Asset based theory, these upper hands this can enable the association to appreciate solid profits (Barney,1991).He continues that to outlines that key assets is a benefit that is significant ,uncommon, hard to mimic , and non-substitutable. An asset is important to the degree that it enables a firm to make techniques that benefit from circumstances and avert dangers. The southwest Airline way of life fits this standard well. The most carriers battle to be productive, yet southwest profits grew basically consistently .his culture is likewise uncommon in that strikes, cutbacks and poor confidence are regular inside the carrier business(Chi,1994; Porter, 1980).

Along the debate has been developed on resource -based theory (RBT) since the 1980s. When the new assumptions of this theory were explicated, deep and strong reactions came out. The main theoretical question that have been constantly posted in the international debate are essentially two:1)how can firms gain their competitive success , that is to say their sustainable competitive advantage,2)why do firms exists? In the last decades, different theories have been developed trying to answer these questions. Among them, some can be regarded as strategic; their main questions are in fact posed from a typical strategic point of view (more attention is paid to the first one of the above questions):In this category, industrial organization contributions have to be considered (Porter ,1980,1985) as well as the strategic side of evolutionary theory (Nelson \& Winter 1982), and resource based theory. These are, in particular, transaction cost economics, agency theory and options theory: they are all based on the assumption that in equilibrium situations or in the long run firms may make the same choices, that is they can arrive at equal results.

Resource-based theory plays an important role in guiding to understand the scope of business enterprises of which women owned enterprises is part. Resource based theory states that those enterprises with resources of value are rare and have the ability of achieving greater output (Wiklund\& Shepherd, 2003). According to resource-based theory there are two classifications of resources which are usually categorized as either property-based resources or knowledge-based resources. In this regard property-based resources are simply the tangible input resources whereas knowledge-based resources are the ways in which entities come together and transform tangible input resources. Based on these classifications, it can be generalized that Knowledge-based 
International Journal of Current Aspects in Finance, Banking and Accounting, Volume 2, Issue 3, 2020 PP 24-37, ISSN 2707-8035

\section{[IJCAB}

resources are of value in providing sustainable competitive advantage. Literacy is a resource and lower levels of literacy hinder women's ability to gain directly in business financing agencies (UNDP, 2015). Credit is a monetary resource which is easily provided by microfinance services and is an example of property based resources as it comprises of essentials such as collateral. Furthermore, an example of knowledge-based resource is financial training characterized by literacy level, credit knowledge, entrepreneurial skills, training policy and expenditure skills of women entrepreneurs. In nutshell; credit and financial training as microfinance services are capitalized by this theory. This theory majorly explains the relationship between credit access and financial training and their impact on women owned entrepreneurs. It is therefore a key theory that binds the concept of microfinance entities and their services to women owned businesses enterprises.

\subsection{Institutional Theory}

Institutional scholars state that the institutional condition can emphatically impact the improvement of formal structures in an association, regularly and more significantly than showcase pressures. Inventive structures that improve specialized productivity in early-receiving associations are legitimized in the earth. At last, these developments arrive at a degree of legitimization where inability to embrace them is viewed as "unreasonable and careless" (or they become lawful orders). Now new and existing associations will receive the auxiliary structure regardless of whether the structure doesn't improve proficiency Meyer and Rowan (2006) contend that frequently these "institutional fantasies" are simply acknowledged ceremoniously all together for the association to pick up or keep up authenticity in the institutional condition. Associations embrace the "vocabularies of structure" common in their condition, for example, explicit occupation titles, methodology, and hierarchical jobs.

The selection and unmistakable presentation of these institutionally-satisfactory "trappings of authenticity" help protect an emanation of authoritative activity dependent on "great confidence". Authenticity in the institutional condition guarantees authoritative endurance. Be that as it may. To lessen negative impact, associations frequently will decouple their specialized center from these legitimizing structures. Associations will limit or ceremonials assessment and disregard program execution to look after outside (and inward) trust in formal structures while lessening their proficiency sway. DiMaggio and Powell (1983) presume that the net impact of institutional weights is to build the homogeneity of hierarchical structures in an institutional situation. Firms will embrace comparable structures because of three kinds of weights. Coercive weights originate from lawful orders or impact from associations they are reliant upon. Mimetic weights to duplicate effective structures emerge during high vulnerability. At long last, regulating weights to homogeneity originate from the comparative frames of mind and approaches of expert gatherings and affiliations brought into the firm through contracting rehearse. They indicate that pace of institutional isomorphism is expanded when firms; are exceptionally subject to the institutional condition, Exist under high vulnerability or equivocal objectives and depend broadly on experts. According to Tolbert \& Zucker 1999) findings on the aspects of development of three managerial administration in California state funded schools; from the outlook of institutional hypothesis .it was found that when there is an elevated level of accord and collaboration inside the institutional condition, dissemination of imaginative structures is consistent and enduring.In any case, when the institutional condition is combative and unfocused ,appropriation of imaginative structures is moderate and speculative. 


\section{[IJCAB}

Tolbert and Zucker (1999) expanded Rowan's discoveries by assessing the pace of appropriation of common assistance associations in the United States from 1880-1935. Their outcomes firmly bolster the institutional hypotheses sketched out above. An institution is similarly an organization and in this context a business entity, therefore for an institution to grow, it focuses on key elements. This theory focuses on the role of social, economic and political systems in which women entrepreneurs conduct their businesses (Baughn, Chua \& Neupert, 2006). It further capture institutional framework whereby an organization in an institution and there exists legal framework which addresses credit policy among other on microfinance services in regard to loan guarantor ability, membership ability, reduction of defaulters, ethics and loan services discipline as well as loan guarantee and lending policies in general.It is noted that women from marginalized and rural social backgrounds are not well informed about business operations and microfinance services hence fail to take advantages of the opportunities as they arise (International Labor Organization, 2014). Therefore women entrepreneurs need technological knowledge on social capital and savings which is appropriate for their entrepreneurial operations (Government of Kenya, 2015).This study while capitalizing on institutional strength which directly refers to microfinance entities or agencies is vital for this study whereby savings and social capital groupings are key institutional services.

\section{Conceptual Framework}

The conceptualization explains the relationship between the dependent and independent variables as influenced by moderating government regulations. Credits are generally on the basis of size and purpose, while the recipients of such credit require sufficient skills and knowledge to effectively and efficiently employ the funds in a productive investment. Financial training as well as savings influence performance of women owned enterprises. On the other hand, social capital elements constitute the dynamic framework under which any business operates. All these can only yield positive outcomes depending on the investment opportunity in the investment environment where the independent variables are made to function through favorable opportunities. The outcomes for businesses may affect the performance measurement such as market share, stock level and sales volume. The realization of these will also be influenced by the business owner's attitude to risk in each line of investment. 
International Journal of Current Aspects in Finance, Banking and Accounting, Volume 2, Issue 3, 2020 PP 24-37, ISSN 2707-8035

\section{[iJCAB}

The stidv was mided hr the nnnseptual framework below;

Independent variable

Microfinance services

Dependent variable

Credit

- Collateral

- Credit policy

- Interest charged

- Demand for credit

- Credit accessibility

Financial Training

- Literacy level

- Financial management skills

- Credit knowledge

- Entrepreneurial skills

- Training policy

- Expenditure skills

\section{Social capital}

- Loan Guarantor ability

- Member accessibility

- Minimize loan default

- Member discipline

- Loan servicing

\section{Savings}

- Credit access ability

- Membership strength

- Collateral base

- Loan Security

- Lending policy

\section{Legal framework}

- Licensing policies

- Taxation policies

- Loan recovery policies

- Training policies

- Lending policies

Figure 1: Conceptual Framework

\section{Performance of Women Owned Business Enterprises' \\ - Market share \\ - Sale volume \\ - Number of branches. \\ - Stock Levels}

Source: Researcher (2020) 
International Journal of Current Aspects in Finance, Banking and Accounting, Volume 2, Issue 3, 2020 PP 24-37, ISSN 2707-8035

[i]CAB

\section{Research Methodology}

The study adopted descriptive survey research design. The design was proper for investigating the impact of microfinance services administrations and the exhibition of women owned business enterprises in Busia County, Kenya.

The objective populace of this examination was small and medium size enterprises in Busia County, Kenya which are 2000 legally registered enterprises according to the data with business name registration bureau and among this number; one thousand two hundred enterprises (1200) are actively involved in executing their entrepreneurial mandates thus mainly in the line of food outlets, retail shops, boutique, salons and communication such as phone accessories shops. Out of the 1200 enterprises in the study target area Busia County $42 \%$ of these enterprises are owned by women thus equivalent to 500 enterprises which form the study target population of women entrepreneurs respectively. In this investigation the examining outline comprised of five different elements of small and medium women owned enterprises thus Food outlets; retail shops Boutiques, Salon, and communications. The studies drew a hundred (100) women entrepreneurs from each category element.

Based on the study sample frame, the study target population was 100 persons who are made up of enterprises proprietors and their key employee managers. A sample size of the study constituted $20 \%$ of the study target population stratums and this was according to Mugenda \& Mugenda 2012 who suggests that a test of between 10-30\% of the target objective populace could be still suitable for the investigation which this investigation (study) utilized. Arbitrary testing was utilized. In general every component of the population had an equivalent possibility of being chosen into the example (Cooper \& Schindler, 2003). The sampling technique used was stratified simple random sampling. The questionnaires were given to the entire hundred (100) target study respondents as per the study sample size. Enough time (1 week) was given for the respondents to give well thought out answers to the questions. Good rapport with the respondents was established through assurance of confidentiality and anonymity of the information given. A follow up to the respondents was done just to remind them over the questionnaires answering and making sure the study attains $100 \%$ response rate. The Statistical Package for Social Sciences (SPSS) was used for analysis and interpretation of data. SPPS was used because it does offer wide ranging basic as well as advanced analytical techniques that enable data processing collected from the respondents (Coaches \&Steed, 2009).Primary data was collected using questionnaires. Both qualitative and quantitative data analysis methods were done by use of SPSS version 23.0 and study findings were presented using frequency tables and bar graphs findings were presented by, Percentages and central tendencies that may include mean, median and mode among others.

\section{Data Analysis Results}

This statistics were based on correlation coefficients, coefficients of determination, analysis of variances and the model coefficients. 
International Journal of Current Aspects in Finance, Banking and Accounting, Volume 2, Issue 3, 2020 PP 24-37, ISSN 2707-8035

[IJCAB

\section{Table 1: Correlation Coefficients}

\begin{tabular}{|c|c|c|c|c|c|c|c|}
\hline & & 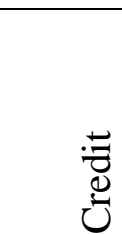 & 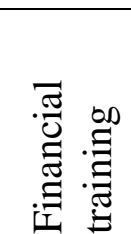 & 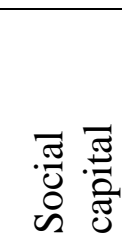 & 崩 & 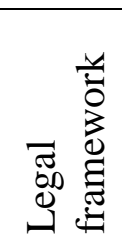 & 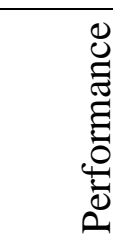 \\
\hline \multirow{4}{*}{ Credit } & Pearson & & & & & & $.972 *$ \\
\hline & Correlation & 1.000 & 0.709 & 0.685 & 0.694 & 0.720 & $*$ \\
\hline & Sig.(2-Tailled) & & 0.000 & 0.000 & 0.000 & 0.000 & 0.000 \\
\hline & $\mathrm{N}$ & 83 & 83 & 83 & 83 & 83 & 83 \\
\hline \multirow{4}{*}{ Financial training } & Pearson & & & & & & $.923^{*}$ \\
\hline & Correlation & 0.709 & 1.000 & 0.674 & 0.660 & 0.679 & $*$ \\
\hline & Sig.. (2-Tailled & 0.000 & & 0.000 & 0.000 & 0.000 & 0.000 \\
\hline & $\mathrm{N}$ & 83 & 83 & 83 & 83 & 83 & 83 \\
\hline \multirow{4}{*}{ Social capital } & Pearson & & & & & & $.893^{*}$ \\
\hline & Correlation & 0.685 & 0.674 & 1.000 & 0.585 & 0.681 & $*$ \\
\hline & Sig.(2-Tailled) & 0.000 & 0.000 & & 0.000 & 0.000 & 0.000 \\
\hline & $\mathrm{N}$ & 83 & 83 & 83 & 83 & 83 & 83 \\
\hline \multirow{4}{*}{ Savings } & Pearson & & & & & & $.925^{*}$ \\
\hline & Correlation & 0.694 & 0.660 & 0.585 & 1.000 & 0.660 & $*$ \\
\hline & Sig.(2-Tailled & 0.000 & 0.000 & 0.000 & & 0.000 & 0.000 \\
\hline & $\mathrm{N}$ & 83 & 83 & 83 & 83 & 83 & 83 \\
\hline \multirow{4}{*}{ Legal framework } & & & & & & & $.925^{*}$ \\
\hline & Pearson correlation & 0.720 & 0.679 & 0.681 & 0.660 & 1.000 & $*$ \\
\hline & Sig.(2-tailed) & 0.000 & 0.000 & 0.000 & 0.000 & & 0.000 \\
\hline & $\mathrm{N}$ & 83 & 83 & 83 & 83 & 83 & 83 \\
\hline \multirow{4}{*}{ Performances } & Pearson & $.972 *$ & $.923^{*}$ & $.893 *$ & $.925^{*}$ & $.925^{*}$ & \\
\hline & Correlation & $*$ & $*$ & $*$ & $*$ & $*$ & 1.000 \\
\hline & Sig.(2 -Tailled $)$ & 0.000 & 0.000 & 0.000 & 0.000 & 0.000 & \\
\hline & $\mathrm{N}$ & 83 & 83 & 83 & 83 & 83 & 83 \\
\hline
\end{tabular}

** The correlation significant at the 0.01 level (2-Tailled)

The above Table 1 clearly reveals a Pearson Correlation coefficient between performance and every explanatory study variables having been found to be significant at both $95 \%$ and $99 \%$ confidence level and 2-test with correlation coefficient being 0.972, 0.923, 0.893, 0.925, 0.925 respectively. It continues to reveal that there exists a very strong relationship between the performance of women-owned business enterprises and legal framework, savings, social capital, financial training, and credit.

Table 2: Coefficient of Determination

\begin{tabular}{cccccc}
\hline & $\begin{array}{l}\mathrm{R} \\
\mathrm{R}\end{array}$ Square & $\begin{array}{c}\text { Adjusted R } \\
\text { Square }\end{array}$ & $\begin{array}{c}\text { Std. Error of the } \\
\text { Estimate }\end{array}$ & $\begin{array}{c}\text { R Square } \\
\text { Change }\end{array}$ & $\begin{array}{c}\text { Durbin- } \\
\text { Watson }\end{array}$ \\
\hline .985 & & & & \\
$\mathrm{a}$ & 0.97 & 0.968 & 0.12807 & 0.97 & 1.774 \\
\hline $\begin{array}{l}\text { a. Predictors: } \\
\text { Credit }\end{array}$
\end{tabular}


International Journal of Current Aspects in Finance, Banking and Accounting, Volume 2, Issue 3, 2020 PP 24-37, ISSN 2707-8035

[IJCAB

\section{b. Dependent Variable: Performance}

Results in Table 2 show an R-Square of 0.968 with the standard error of estimate being 0.128 . This implies that using composite score, legal framework, savings, social capital, financial training, and credit significantly influences performance of women-owned business enterprises. The researcher also tested for autocorrelation using Durbin Watson statistic which is always between 0 and 4 where a value of 2 means that there is no presence of autocorrelation in the residuals (prediction errors) from a regression analysis. The Hypotheses for the Durbin Watson test are:

$\mathrm{H} 0=$ No first order autocorrelation

$\mathrm{H} 1=$ First order correlation exists.

(For a first order correlation, the lag is one-time unit).

A rule of thumb is that, test statistic values in the range of 1.5 to 2.5 are relatively normal. Values outside of this range could be cause for concern. Field (2009) suggests that values under 1 or more than 3 are a definite cause for concern. For the current study, Durbin Watson statistic was 1.774 which falls within the relatively-normal range and therefore there was no autocorrelation in the residuals from regression analysis.

The Table 3 Analysis of Variance

\begin{tabular}{cccccc}
\hline \multicolumn{7}{c}{ Sum of } & & & & \\
& Squares & df & Mean Square & F & Sig. \\
\hline Regression & 40.683 & 5 & 8.137 & 496.077 & $.000 \mathrm{a}$ \\
Residual & 1.263 & 77 & 0.016 & & \\
Total & 41.946 & 82 & & & \\
\hline$i$. & Predictors: (Constant), Legal Framework, Savings, Social Capital, Financial \\
& Training, Credit & & \\
$i$ ii. & Dependent Variable: Performance & & & \\
\hline
\end{tabular}

As shown in Table 3, F-Calculated $(5,77)=496.077$ which is greater than F-Critical $(5,77)=3.96$ at 2 -tail test and $95 \%$ confidence level. Results also show that $p$-value $=0.000<0.05$. The findings continues to confirm that the predictors positively and significantly does affect the performance of women-owned business enterprise fund.

The Table 4 - Model Coefficients

\begin{tabular}{lccccc}
\hline & \multicolumn{3}{c}{ Un standardized Coefficients } & \multicolumn{3}{c}{ Standardized Coefficients } \\
& $\mathrm{B}$ & Std. Error & Beta & $\mathrm{t}$ & Sig. \\
\hline (Constant) & 0.026 & 0.094 & & 0.275 & 0.784 \\
Credit & 0.502 & 0.065 & 0.505 & 7.714 & 0.000 \\
Finance Literacy training & 0.124 & 0.048 & 0.134 & 2.572 & 0.012 \\
Social capital & 0.081 & 0.042 & 0.094 & 1.923 & 0.038 \\
Savings & 0.236 & 0.047 & 0.236 & 4.985 & 0.000 \\
Legal framework & 0.059 & 0.058 & 0.057 & 1.01 & 0.015 \\
\hline
\end{tabular}

a. Dependent Variable: Performance 
International Journal of Current Aspects in Finance, Banking and Accounting, Volume 2, Issue 3, 2020 PP 24-37, ISSN 2707-8035

\section{[iJCAB}

Findings presented in Table 4 show that each of the predictors is held constant, water performance of women-owned business enterprises will remain at 0.026. At the same time, an increase in credit, financial literacy training, social capital, savings, and legal frame work by one unit leads to an increase in performance by $0.502,0.124,0.081,0.236$, and 0.059 units respectively with a p-value of $<0.05$ for each variable. The summary of the above can be clearly expressed by the following model: $Y=0.026+0.502 X_{1}+0.124 X_{2}+0.081 X_{3}+0.236 X_{4}+0.059 X_{5}$. These findings confirm that, microfinance organizations empower venture proprietors to build up their smaller scale and little endeavors, which upgrade their salary acquiring limit, and consequently appreciate an improved expectation for everyday comforts. Though numerous MFIs developed to give beginning and working capital in Kenya, importance and cost-adequacy is frequently wrong in fulfilling the specific needs of potential and working women business visionaries (Government of Kenya, 2014). The presence of microfinance establishments empowers the potential customers to get to the administrations given by the foundations. These administrations give the customers chance to help their endeavors, monetary exercises just as their family unit budgetary administration and utilization need. Nonetheless, Majority of researchers insists that in underdeveloped and developing countries such as Kenya, women entrepreneurs are underfunded which creates a problem in running of their businesses. It is upon this underfunding that special funds concept that includes microfinance and women fund emerged to bridge this gap. More continues to indicate that in the developing economy at large; the aspect of women accessing to funding is quite limited because lending agencies usually require tangible and substantive collateral from borrowers.

\section{Conclusion}

Based on the study findings, the study conclude that, women owned business enterprises are key drives to the economic development in Kenya, therefore the study recommends that the training program should be emphasized to enhance the literacy of financial management for exemplary performance of the enterprises. Savings, social capital, financial training, legal framework, and credit services significantly has enormous influence on performance of women-owned business enterprises. Correspondingly, Women entrepreneurs do possess entrepreneurial skills, financial literacy, and ability to read and interpret financial matters and attending business exhibitions and trainings which are important factors for success of business ventures.

Though credit on the other hand is highly demanded by women entrepreneurs, access to credit has not been easy for their businesses. Moreso it has been cited as a critically to be an uphill task accessing to credit among women entrepreneurs, especially among formal financial institutions such as banks. Social capital set up has largely assisted women-owned business enterprises to easily secure credit through member guarantors. This is a major improvement as microfinance institutions are able to subscribe more clients through social capital set ups. Members' savings are key in making women enterprise strong and thus easily access credit. The results are expected given that saving is major force in microfinance as it becomes a security for credit access. As revealed in this study, microfinance organizations are able to get many customers based on their credit policy. Therefore, it is essential to set up an official credit arrangement when an organization gives credit terms to its real products just as administrations.

\section{Recommendations}

Based on the research findings, this study presents some of the key policy recommendations that could enhance the effectiveness of women-owned business enterprises: Financial literacy training 
International Journal of Current Aspects in Finance, Banking and Accounting, Volume 2, Issue 3, 2020 PP 24-37, ISSN 2707-8035

\section{[iJCAB}

programs for women-owned enterprises could be more effective if designed to meet the standards needs for women entrepreneurs and the new entrants who are interested but little knowledge on business operations and sustainability. In addition, the frequency of training should be increased to keep them abreast with modern methodologies for better performance. Budgeting skills, book keeping and accounting skills training programs were found to play a very significant role in growing sales, profits and ensuring smooth running of women led enterprises.

For real long waited positive impact among women entrepreneurs 'there is dire need to tailorMake financial structures and policies that could accelerated and enhance access to affordable and trustworthy financial services empower women as individuals within their households as well as a group within their communities. Credit should be made accessible to women as well as affordable. Micro-Finance institutions should not only avail credit to women but also empower them with skills on how to manage it so that it can be of economic benefit to them. Among others viable community socio economic structures, Self-help groups through social guarantors should be encouraged as they accommodate the lower bracket in the income levels. Table banking should be encouraged where women meet in their groups, save and borrow. The study strongly recommends formulation of a policy framework to ensure prudent, efficient and effective use of loans obtained from microfinance in line with the objectives of the fund. The study further recommends for more detailed investigation on individual women's access to finances and empowerment of women on governance with larger sample needs to be undertaken in more districts.

\section{References}

Bank of International Settlements (2014). Progress report on Basel III Implementation. Basel Committee on Banking Supervision: http://breakingintowallstreet.com.

Central Bank of Kenya. (2015). Annual Bank supervision Reports: https://www.centralbank.go.ke/index.php/banksupervision

Inter-American Development Bank (2015). Women entrepreneurs: too often trapped in the microenterprise ghetto.

International Finance Corporation (2018).Strengthening Access to Finance for Women-Owned SMEs in Developing Countries

Karani P. (2012). Resource Banking Meeting, Kenya Institute of management. Innovative approaches can boost women's economic presence among small business owners in Latin America and the Caribbean

Kariuki, P. W. (2012). Effects of liberation on access to bank credit in Kenya economy. Paper presented at the ASBBS Annual Conference: Las Vegas.

Kiraguri, G. (2012). Social cultural barriers affecting the women entrepreneurs in Kenya. Nairobi: Federation of Women Entrepreneurs Association.

Kongolo, M. (2010). Job creation verses job shedding and the role of SMEs in economic development. African Journal of Business Management, 4(11), 2288-2295.

Kothari, R. C. (2010). Research methodology: Methods and techniques. New Delhi: New Age International (P) Publishers.

Mbogo, S. (2013). Kenyan SMEs hungry for funding. The East African Newspaper, Nairobi.

Miles, D. J., Yang, \& Marcheggiano. G. (2015). Optimal bank capital. Discussion Paper No 453 .Bank of England.

Mugenda, O. M. \& Mugenda, A. G. (2012).Research Methods: Quantitative and Qualitative Approaches. $2^{\text {nd }}$ Ed. Nairobi: ACTS Press 
International Journal of Current Aspects in Finance, Banking and Accounting, Volume 2, Issue 3, 2020 PP 24-37, ISSN 2707-8035

iJCAB

Murinde, V. (2014). Bank Regulation in Africa: From Basel I to Basel II, and Now at Crossroads. In Victor Murinde (Ed), Bank Regulatory Reforms in Africa. Palgrave: MacMillan.

Mwobobia, F. M. (2012). The Challenges Facing Small-Scale Women Entrepreneurs: A Case of Kenya. International Journal of Business Administration, ISSN 1923-4007(Print) ISSN 1923-4015

OECD-MENA (2011, February).Women's Access to Finance in the Middle East and North America

Republic of Kenya (2011).Kenya National Bureau of Statistics. Vision 2030: Where we Were, where we are and where we are headed. Nairobi: Government Press.

Sena, V., Scott, J., \& Roper, S. (2012). Gender, borrowing patterns and self-employment: some evidence for England. Small Business Economics, 38(4), 467-480.

Waita, J. M. (2012). Challenges facing women in accessing credit from microfinance institutions in Nakuru. Nairobi: University of Nairobi.

Watson, J. (2012). Networking: Gender differences and the association with firm performance. International Small Business Journal, 30(5), 536-558.

Wiklund, J.\& Shepherd, D. (2003).Knowledge-based resources, entrepreneurial orientation, and the performance of small and medium-sized business.Strategic Management Journal, 24. 1307 - 1314.

Women-owned business enterprises (2012) Status of Women-owned business enterprises, 2012. Nairobi: Ministry of Gender, Children and Social Development.

Yusuf S A, A. J. (2014). Effect of microfinance on small scale enterprise in Osun State, Nigeria. American Journal of Contemporary Research, 4 (6).

This is an open-access article published and distributed under the terms and conditions of (c) (†) (8)

the Creative Commons Attribution 4.0 International License of United States unless otherwise stated. Access, citation and distribution of this article is allowed with full recognition of the authors and the source. Authors seeking to publish with an Internationally Peer Reviewed Journals should consider https://www.ijcab.org/ by writing to the Editor at editor@ijcab.org or submitting online at https://journals.ijcab.org/journals/index.php. The articles must be quality and meet originality test.

$\frac{\text { IJCAB }}{\text { Publishing Group }}$ 